\title{
Changes of sub-fossil chironomid assemblages associated with volcanic sediment deposition in an Andean lake $\left(38^{\circ} \mathrm{S}\right)$, Chile
}

\author{
Cambios en las asociaciones sub-fósiles de quironómidos, producto de la depositación \\ de sedimentos volcánicos en un lago andino $\left(38^{\circ} \mathrm{S}\right)$, Chile
}

\author{
ALBERTO ARANEDA ${ }^{1,2, *}$, FABIOLA CRUCES $^{3,1}$, LAURA TORRES $^{3,1}$, SEBASTIEN BERTRAND $^{4}$, \\ NATHALIE FAGEL ${ }^{4}$, HANS C. TREUTLER ${ }^{5}$, LUIS CHIRINOS ${ }^{1,6}$, RICARDO BARRA $^{2}$ \& ROBERTO URRUTIA ${ }^{1,2}$ \\ ${ }^{1}$ GEP (Grupo de Estudios Paleolimnológicos), Unidad de Sistemas Acuáticos, Centro EULA Universidad de Concepción, \\ Casilla 160-C, Concepción, Chile \\ ${ }^{2}$ Unidad de Sistemas Acuáticos, Centro EULA Universidad de Concepción, Chile \\ ${ }^{3}$ Departamento de Botánica, Universidad de Concepción \\ ${ }^{4}$ Clays and Paleoclimate Research Unit, Department of Geology, University of Liege, Belgium \\ ${ }^{5}$ UFZ-Centrum, Leipzig, Germany \\ ${ }^{6}$ Departamento de Ingeniería, Pontificia Universidad Católica del Perú, Perú \\ *e-mail for correspondence: aaraneda@udec.cl
}

\begin{abstract}
Chironomid assemblages and sedimentological parameters (grain size, organic content, mineralogy) of a short sediment core from Lake Galletué $\left(38^{\circ} 41^{\prime} \mathrm{S}, 71^{\circ} 17^{\prime} \mathrm{W}\right)$ were analysed. The sedimentary record includes one volcanic ash (tephra) layer, which has a completely different composition than the host sediment in terms of organic content, grain size, and mineralogy. According to the geochronology $\left({ }^{210} \mathrm{~Pb}\right.$ and $\left.{ }^{137} \mathrm{Cs}\right)$, this ash layer corresponds to the eruption of Llaima Volcano in 1956-1957. The tephra deposition had an impact on chironomid assemblages producing, among other changes, an increase in Parakiefferiella and a decrease in Ablabesmyia, although no noticeable change was detected in the diversity index. When compared with other studies, our results also show an impact in terms of the presence of chironomid head capsules within the tephra. The presence of these head capsules could result from the effects of percolation, since the coarse grain size of the tephra particles provides large interstitial spaces. The recovery in the abundances of some taxa after the tephra input, suggests the lake is probably restoring the conditions prevailing before the tephra fall.
\end{abstract}

Key words: chironomids, lake sediments, tephra layer, southern Chile.

\section{RESUMEN}

Se analizan las asociaciones de restos sub-fósiles de quironómidos y los parámetros sedimentológicos de un núcleo sedimentario del lago Galletué ( $\left.38^{\circ} 41^{\prime} \mathrm{S}, 71^{\circ} 17^{\prime} \mathrm{O}\right)$. Es evidente en este núcleo la presencia de un estrato de sedimentos volcánicos (tefra) de una composición distinta en el contenido de materia orgánica, en el tamaño de partícula y en la mineralogía, respecto de los sedimentos del lago. De acuerdo a la geocronología isotópica $\left({ }^{210} \mathrm{~Pb}\right.$ y $\left.{ }^{137} \mathrm{Cs}\right)$, los sedimentos de esta tefra podrían corresponder a la erupción del volcán Llaima de 1956-1957. Por otra parte la depositación de esta tefra también provocó un cambio en las asociaciones de quironómidos, siendo evidente el aumento de Parakiefferiella y la disminución de Ablabesmyia dentro del estrato de tefra. Si bien nuestros resultados, al igual que estudios previos, registran un cambio en las asociaciones de quironómidos debido a la entrada de sedimentos volcánicos, un aspecto diferente es la presencia de cápsulas cefálicas dentro de la tefra. Una posible explicación a tal diferencia podría ser la percolación de los restos de quironómidos por los espacios intersticiales de la tefra. La recuperación en la abundancia de algunos taxa luego de la depositación de la tefra, sugiere que el lago restablecería las condiciones existentes previo a la caída de la tefra.

Palabras clave: quironómidos, sedimento lacustre, estrato de tefra, Chile.

\section{INTRODUCTION}

Chironomids (Insecta: Diptera) have been used extensively, mainly in the northern hemisphere, to study the past climate, trophic status of lakes, oxygenation levels, and water quality, among others (Walker 1987, Walker et al. 1991, Walker et al. 1995, Heinrichs et al. 1997, Olander et al. 1997, Brooks \& Birks 2000, 2004, Brooks et al. 2001, Larocque et al. 2001, 
Little \& Smol 2001, Quinlan \& Smol 2001, Adriaenssens et al. 2004). These insects make good paleolimnological indicators because they are abundant in many water bodies, the larval head capsules preserve well in sediments, and the winged adult stages are highly mobile, enabling them to disperse over wide areas (Brooks 2000, Massaferro \& Brooks 2002). Despite their usefulness as environmental indicators, chironomids are rarely used as such outside of the Northern Hemisphere, especially not in southern South America, where only a few studies focus on this insect group.

Specifically in Chile, little is known about the taxonomy and paleo applications of chironomids. Brundin (1983) identified a new sub-family for Chile, Chilenomyinae, comprising only one species: Chilenomya paradoxica. Later, Arenas (1995) studied the composition and distribution patterns of zoobenthos in the Biobío River, identifying 25 chironomid taxa; the genus Cricotopus occurred throughout the river. Andersen (1996) described a new chironomid species, Monodiamesa mariae, from southern Chile (Los Palos River; 45 ${ }^{\circ} 23^{\prime}$ S, $72^{\circ} 41^{\prime}$ W).

Recently, Massaferro et al. (2002) found 49 chironomid taxa at Laguna San Rafael National Park $\left(46^{\circ} \mathrm{S}\right)$. The subfamily Orthocladiinae was clearly predominant, followed by Tanypodinae, Podonominae, and Chironominae. In another work, Massaferro \& Brooks (2002) carried out the first study of sub-fossil chironomid assemblages in Chile at Laguna Stibnite $\left(46^{\circ} 25^{\prime} \mathrm{S}, 74^{\circ} 24^{\prime} \mathrm{W}\right)$, relating chironomid assemblages to environmental changes developed during the Late Quaternary. The authors found 34 chironomid taxa that reflected environmental changes throughout the Lateglacial and the Holocene.

Only a few references address the impact of volcanic eruptions on chironomid assemblages and other aquatic biota in South America (Massaferro \& Corley 1998, Massaferro et al. 2005), although Eastwood et al. (2002) found that volcanic eruptions can have substantial impacts on natural ecosystems and that volcanic depositions provide an opportunity to evaluate species interactions and ecosystem resilience (Lotter \& Birks 1993, Barker et al. 2000).

Some studies, mainly in the Northern Hemisphere, have focused on evaluating ecosystem responses to volcanic impacts. Birks \& Lotter (1994) described the changes in diatom assemblages after a tephra deposition near Laacher See volcano, Germany. Changes in diatom production were found in British Columbia as an effect of tephra deposition (Hickman and Reasoner 1994). Heinrichs et al. (1999) reported changes in chironomid assemblages at Kilpoola Lake (British Columbia) after the deposition of an ash layer, and Tsukada (1967) found decreased abundance of Tanytarsus genuinus after two events of volcanic sediment deposition in Lake Nojiri, Japan. Recently, Massaferro et al. (2005) used chironomid assemblages to reveal short term environmental changes in Lake Morenito of the Argentinean Patagonia $\left(41^{\circ} \mathrm{S}\right.$, $71^{\circ} \mathrm{W}$ ), with volcanism being the most important factor affecting the chironomids.

The principal aim of this study was to record the changes in chironomid assemblages after a volcanic event (tephra layer) using a short sediment core from Lake Galletué (Region IX); this is the first study of sub-fossil chironomid assemblages from an Andean lake in Chile. The study of how a volcanic event could affect chironomid assemblages is important as it allows us to disentangle this response from other environmental impacts.

\section{MATERIAL AND METHODS}

\section{Study site}

Lake Galletué (Fig. 1) is located at $38^{\circ} 41^{\prime} \mathrm{S}$, $71^{\circ} 17^{\prime} \mathrm{W}$ in central Chile at an altitude of $1,150 \mathrm{~m}$. It is approximately $26 \mathrm{~km}$ from the nearest city, Lonquimay. The lake has a surface of $12.5 \mathrm{~km}^{2}$ and the maximum depth is $45 \mathrm{~m}$. It is an oligotrophic, monomictic temperate lake with summer stratification (Parra et al. 1993). The lake experiences a steep seasonal gradient in air temperature with extremes of $-6.0{ }^{\circ} \mathrm{C}$ in winter and $28.9^{\circ} \mathrm{C}$ in summer. Annual average precipitation is $1,900 \mathrm{~mm}$ with a maximum of $3,018 \mathrm{~mm}$ and a minimum of $1,180 \mathrm{~mm}$ (Parra et al. 1993).

According to Mardones et al. (1993), different vegetational associations are found in the Lake Galletué watershed. A typical temperate rainforest composed mostly of Nothofagus pumilio (Poepp. \& Endl.), 
Nothofagus dombeyi ((Mirb.) Oerst.), and Araucaria araucana ((Mol.) K Koch) covers the north-north eastern portion of the watershed, with upper levels of this forest reaching 35 to $50 \mathrm{~m}$ high. The mid-levels are composed mainly of young individuals of the same species, whereas the understorey is dominated by Berberis spp. (michay), Drimys winteri var. andina, and the Chilean bamboo Chusquea sp. (quila). The east-south eastern section of the watershed is covered with a high prairie grassland, called "coironal" that covers important areas of the prairie next to the lake and grows in a cushion form called "champas".
The typical composition of this association is marked by the predominance of Festuca scabriuscula (Phil.), Acaena sericea (Jacq.fil.), Baccharis magellanica (Radín), and Rumex acetosella (Linnaeus). This community of low vegetation can be also mixed with Nothofagus antarctica (G. Forster, Oerst.) and A. araucana forests. In the wetland zones near the lake, Juncaceae and Ciperaceae species occur together with the herbaceous genera Trifolium, Melilothus, and Caltha (Mardones op. cit.). These communities indicate the lake has relatively pristine vegetation in its surrounding areas.

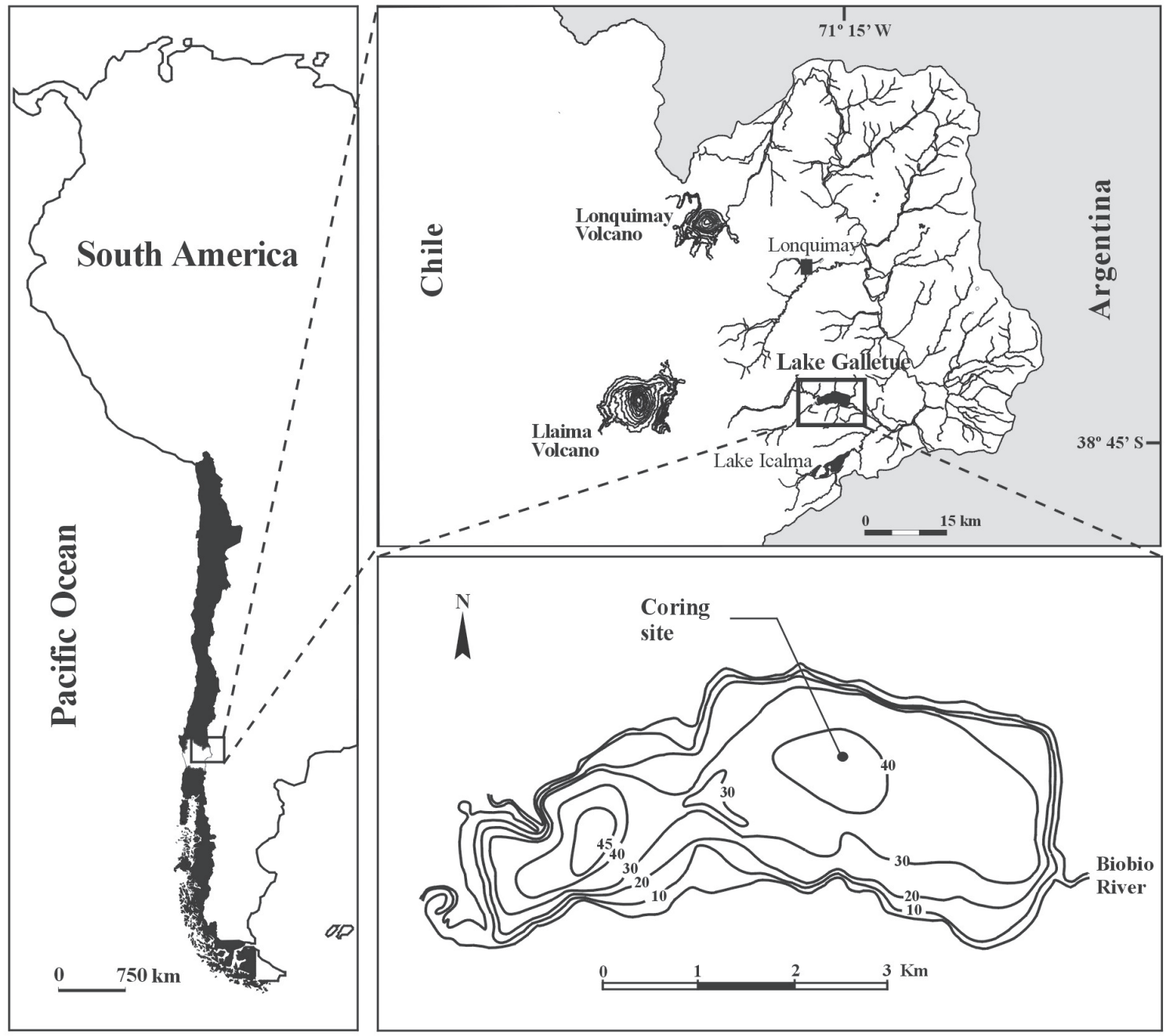

Fig. 1: Study site indicating the location of Lake Galletué.

Área de estudio indicando la localización del lago Galletué. 


\section{Sampling and physical analysis}

A Lowrance X-16 echo sound profiler was used to locate the maximum depth of the lake and a $17-\mathrm{cm}$ sediment core was retrieved using an Uwitec gravity corer with a plexiglass tube (6 $\mathrm{cm}$ diameter). Later, the core was sliced at $1 \mathrm{~cm}$ intervals.

In order to assess the lithology, the core was $\mathrm{x}$-rayed (at $50 \mathrm{kV}$ and $26-30 \mathrm{~mA} \mathrm{~s}^{-1}$ ) following the method outlined by Axelsson (1983). The $\mathrm{x}$-ray inspection clearly identified a high reflectance sediment layer, which was separated for mineralogical analysis. The chemical composition (major elements) of this sediment layer was determined using an electron microprobe (Cameca SX50) at the Centre d'Analyse par Microsonde pour les Sciences de la Terre, Louvain-la-Neuve University (CAMST). The accelerating voltage was $15 \mathrm{kV}$ and the beam current was $20 \mathrm{nA}$. Counting times were $20 \mathrm{sec}$ for all elements.

For grain size analysis, samples were sieved at 4.0 and 1.0 phi units in order to separate the sample into fine (mud) and coarse (sand) fractions. Grain size was analyzed using an Elzone 282 PC Coulter Counter particle analyzer. The organic content in each layer was estimated by loss on ignition (LOI) following the method described by Boyle (2002).

\section{Geochronology}

The age of the core was determined through the activity of ${ }^{210} \mathrm{~Pb}$. The gammaspectrometrical measurements were done using an HPGe detector with a $0.5 \mathrm{~mm}$ beryllium window and an energy resolution of $570 \mathrm{eV}$ at the level of $122 \mathrm{eV}$. The detector and the measuring geometry were calibrated with certified reference material (RGU-1, RGth-1, RGK-1) from the International Atomic Energy Agency (IAEA). Once the activity of each sample was obtained, the age models CIC and CRS (Appleby \& Oldfield 1978) were evaluated in terms of age-depth profile and coherency with the peak in ${ }^{137} \mathrm{Cs}$ activity. The CIC was the most adequate model. The estimated age was validated with the peak in ${ }^{137} \mathrm{Cs}$ activity, which was observed around 1963, when large quantities of this isotope were released into the atmosphere from nuclear weapons tests (Longmore et al. 1983).

\section{Chironomids}

For the chironomid analysis, $4 \mathrm{ml}$ of wet sediment were deflocculated in $10 \% \mathrm{KOH}$ for 15 minutes at $70^{\circ} \mathrm{C}$ and passed through a 90 $\mu \mathrm{m}$ sieve. Later, the remains were transferred to a Bogorov counting tray and head capsules were picked out with entomological forceps. Each head capsule was dehydrated in 80 and $100 \%$ ethanol and then mounted, ventral side up, in euparal. The insects were identified using a Zeiss microscope $(25,40$, or $100 \mathrm{x})$ and the keys of Hofmann (1971), Wiederholm (1983), Epler (2001), Paggi (2001), and Rieradevall \& Brooks (2001).

The relative abundance of each taxon was presented as a percentage of the total abundance in each centimetre using the programs TILIA and TILIA GRAPH. To distinguish different associations along the profile, a stratigraphically constrained sum-of-squares cluster analysis (CONISS) was applied. Zonation was applied when examining major differences in CONISS groupings; their significance levels were evaluated with a one-way analysis of similarities (ANOSIM), with zones as factors using the program Primer E.v. 6.12 (Clarke \& Gorley 2005). This analysis tests for differences among factors using permutation and randomization methods based on the similarity matrix BrayCurtis (Clarke et al. 2005). At the same time to determine which taxa were the most important in to contribute to the differences among the groups, we used the similarity percentage procedure (SIMPER; Primer v.5, Clarke \& Gorley 2001) on transformed variables. In order to relate chironomid assemblages to environmental variables, ordination analyses were performed using the programs CANOCO and CANODRAW. Chironomid diversity and equitability were estimated through the Shannon index, using the program BioDiversity v2.

\section{RESULTS}

\section{Physical parameters}

The radiograph of the Lake Galletué sediment column is depicted in Fig. 2A. A clear high reflectance sediment layer (white area) present between 7 and $12 \mathrm{~cm}$ indicates higher density than in the rest of the core. A first visual 
inspection revealed coarse, dark, irregular, and very sharp particles, probably belonging to a tephra layer. According to the microprobe analysis, the chemical composition of this tephra corresponds to basaltic andesite with $54.29 \% \mathrm{SiO}_{2}$ and $4.32 \% \mathrm{Na}_{2} \mathrm{O}+\mathrm{K}_{2} \mathrm{O}$.

The organic content (LOI) follows a trend related to the tephra layer (Fig. 2B), with a noticeable decrease in the section of core where the tephra layer is evident $(7-12 \mathrm{~cm})$. The highest organic content $(17.2 \%)$ was found at 6 $\mathrm{cm}$, and the lowest $(2.3 \%)$ at $10 \mathrm{~cm}$ (within the volcanic layer). The lower organic content in the volcanic layer is due to its inorganic nature.

Grain size analysis (Fig. 2C) shows an increase in particle size in the tephra layer, passing texturally from silt to sand (mean size $6.83 \mathrm{phi}=8.8 \mu \mathrm{m}$ to $2.16 \mathrm{phi}=223 \mu \mathrm{m})$. A more detailed description of the grain size of this tephra is presented in Fig. 3, where two populations of particle sizes are evident. The coarser population corresponds to the tephra layer, with a mean size around 600-900 $\mu \mathrm{m}$, and the finer population belongs to the host sediment with a diameter below $63 \mu \mathrm{m}$. Also, the circular diagrams indicate that the lower sample $(11-12 \mathrm{~cm})$ has the highest proportion of mud. Below the tephra layer, the sediment is composed mainly of silt (Fig. 2C).
The activity of ${ }^{210} \mathrm{~Pb}$ and ${ }^{137} \mathrm{Cs}$ are presented in Fig. 2D and 2E, respectively. The activity of ${ }^{210} \mathrm{~Pb}$ shows a general decreasing trend toward the deepest part of the core. However, some reversal of the ${ }^{210} \mathrm{~Pb}$ activity can be seen in centimetres 2, 3, and 4 with respect to the first and fifth centimetres. ${ }^{210} \mathrm{~Pb}$ activity is highest $\left(375 \mathrm{~Bq} \mathrm{~kg}^{-1}\right)$ in the first $\mathrm{cm}$ and lowest at 16 $\mathrm{cm}\left(8.0 \mathrm{~Bq} \mathrm{~kg}^{-1}\right)$. The total ${ }^{210} \mathrm{~Pb}$ inventory in the core reached $2,351 \mathrm{~Bq} \mathrm{~kg}^{-1}$, indicating that the total flux of ${ }^{210} \mathrm{~Pb}$ to the sediments is 73.2 $\mathrm{Bq} \mathrm{m}^{-2} \mathrm{yr}^{-1}$. The ${ }^{210} \mathrm{~Pb}$ profile reveals an evident relationship with the stratigraphy, as ${ }^{210} \mathrm{~Pb}$ activity decreased after the tephra deposition. This drop could be explained by a dilution of ${ }^{210} \mathrm{~Pb}$ due to an abrupt input of volcanic sediments into the lake. The uniform mineralogical composition of the tephra layer implies that this input had the same origin and was generated in a relatively short period of time (Fig. 2F).

The ${ }^{137} \mathrm{Cs}$ activity (Fig. 2E) is detectable as of $4 \mathrm{~cm}\left(19.0 \mathrm{~Bq} \mathrm{~kg}^{-1}\right)$ and peaks at $7 \mathrm{~cm}(35.0$ $\mathrm{Bq} \mathrm{kg}^{-1}$ ). From 10 to $17 \mathrm{~cm}$, the activity is not detectable. According to Longmore et al. (1983), the peak in ${ }^{137} \mathrm{Cs}$ activity probably represents the year 1963, when this radioisotope was released in large quantities during nuclear weapons tests. There is good agreement between the ${ }^{137} \mathrm{Cs}$ and ${ }^{210} \mathrm{~Pb}$ profiles.

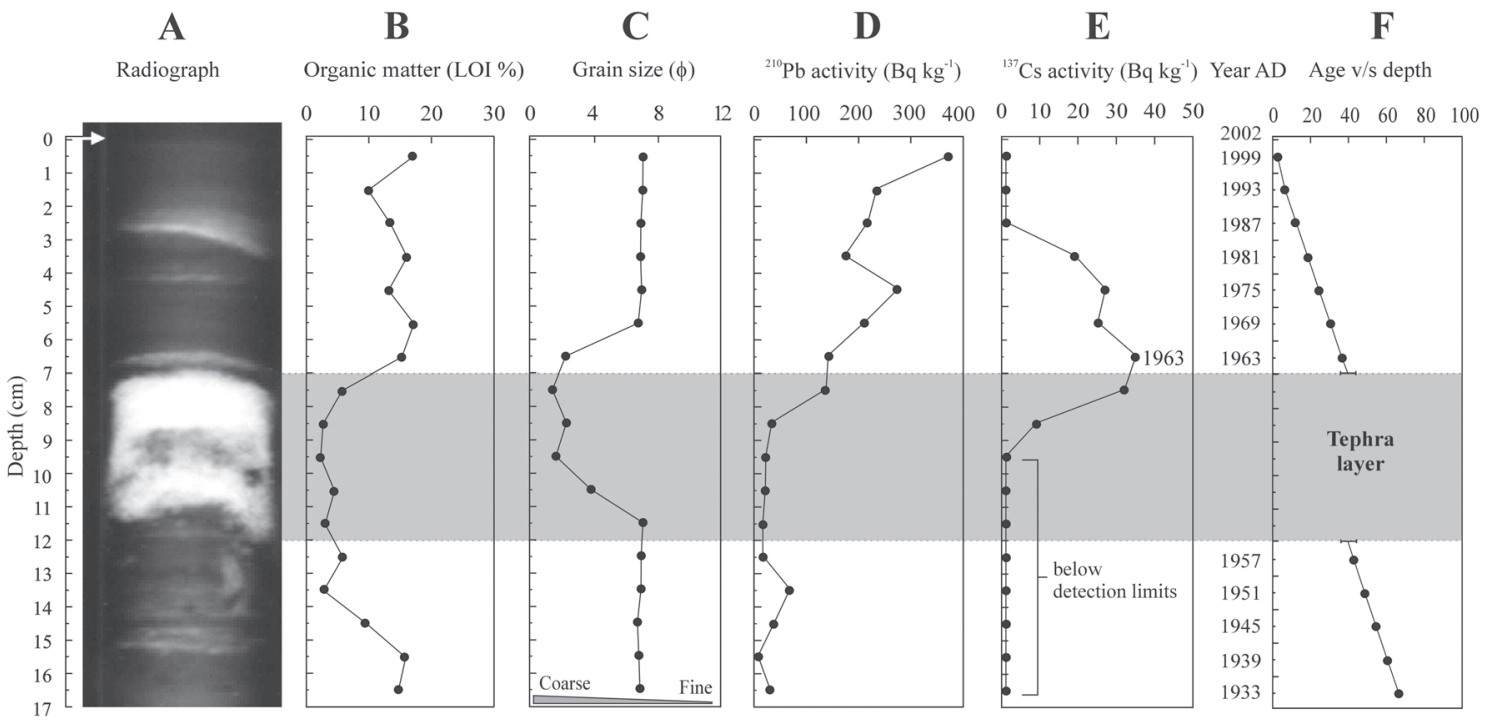

Fig. 2: Physical parameters of Lake Galletué sediment core. (A) X-rays, (B) organic matter, (C) grain size, (D) ${ }^{210} \mathrm{~Pb}$ activity, (E) ${ }^{137} \mathrm{Cs}$ activity, and (F) age versus depth profile.

Parámetros físicos del núcleo sedimentario del lago Galletué. (A) rayos-x, (B) materia orgánica, (C) tamaño medio, (D) actividad de ${ }^{210} \mathrm{~Pb},(\mathrm{E})$ actividad de ${ }^{137} \mathrm{Cs}$ y $(\mathrm{F})$ perfil edad versus profundidad. 


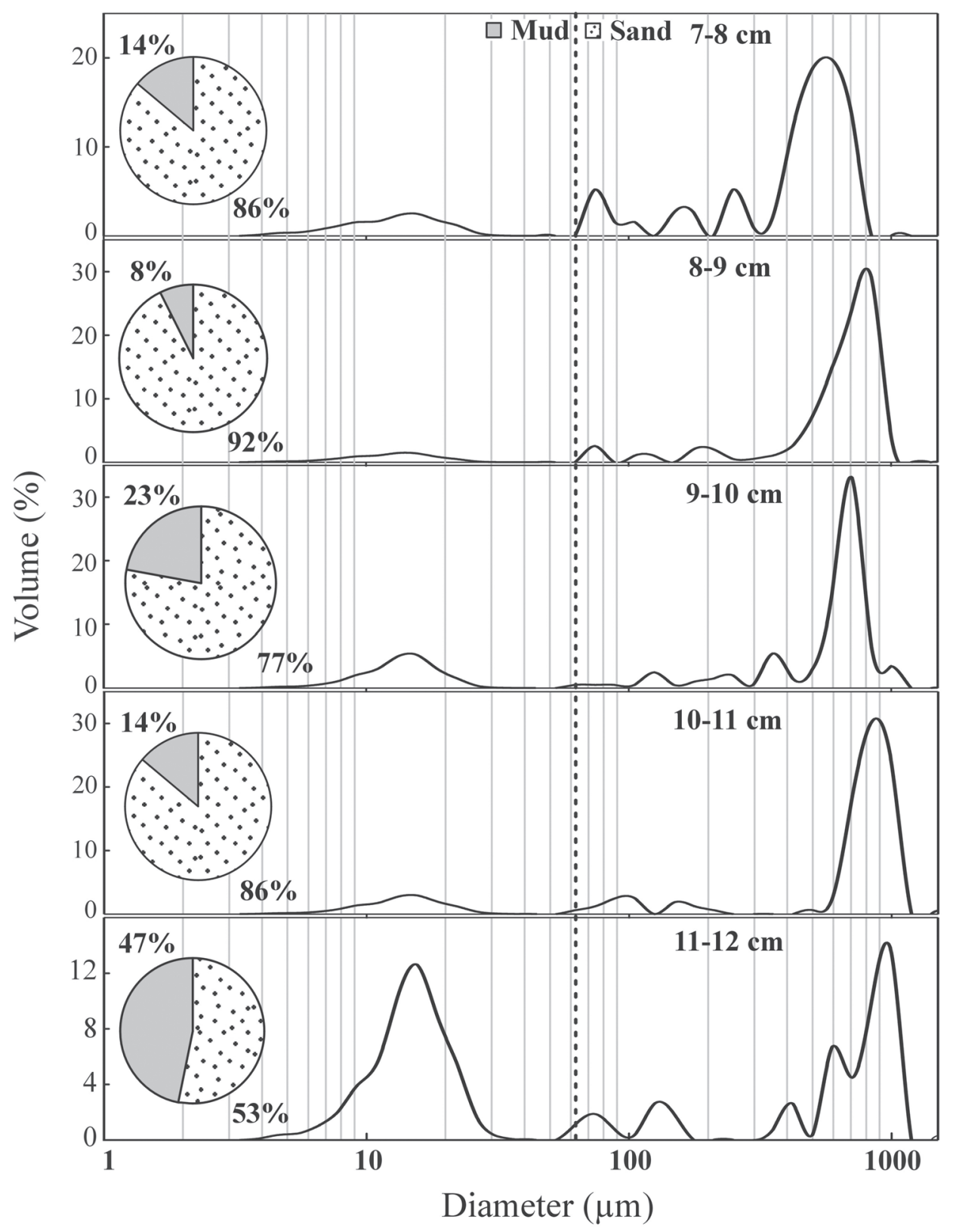

Fig. 3: Grain-size distribution of the five centimetres where the tephra layer is evident; pie diagrams indicate sand-mud proportion. The lower sample $(11 \mathrm{~cm})$ has the highest proportion of mud, reflecting the initial mixing of tephra particles (coarse) with the host sediment (fine).

Distribución del tamaño medio de los sedimentos en los cinco centímetros donde es evidente la tefra. Los diagramas circulares indican la proporción arena/fango. El centímetro inferior $(11 \mathrm{~cm})$ tiene la proporción más alta de fango, reflejando la mezcla inicial de las partículas de tefra (gruesas) con el sedimento lacustre (fino). 


\section{Chironomid assemblages}

A total of 23 chironomid taxa (sub-families Chironominae, Tanypodinae, Orthocladiinae, Podonominae) were identified in the sediment column of Lake Galletué. The most important sub-family in terms of abundance was Chironominae, composed of the tribes Tanytarsini $(25.7 \%)$ and Chironomini (11.4\%), and reaching $37.1 \%$ of the total. The second sub-family in importance was Tanypodinae $(29.1 \%)$, followed by Orthocladiinae $(27.1 \%)$. The sub-family Podonominae had a very low abundance $(0.3 \%)$. Unidentified remains represented $6.3 \%$ of the total. Two different groups of Tanytarsini (types $\mathrm{A}$ and $\mathrm{B}$ ) were distinguished based on differences mainly in the shape of antennal pedestal. Type A is characterized by an antennal pedestal with a low and rounded spur, whereas Type B has an antennal pedestal with a longer rounded spur at an obtuse angle to the pedestal.

The chironomid assemblages in the Lake Galletué sediments are presented in Fig. 4. Using CONISS analysis, three zones were distinguished in the chironomid assemblages. Zone I (17-12 cm) before the impact of the tephra layer, Zone II $(12-6 \mathrm{~cm})$ during the impact, and Zone III $(6-1 \mathrm{~cm})$ after the impact. The one way ANOSIM analysis, indicated significant differences among the taxa abundances of the zones identified by CONISS (ANOSIM, $\mathrm{R}_{\text {Global }}=0.36, \mathrm{P}=0.001$ ) and in the paired comparisons $\left(\mathrm{R}_{\text {zones III-II }}=0.41, \mathrm{P}=0.002\right.$, $\left.\mathrm{R}_{\text {zones III-I }}=0.44, \mathrm{P}=0.002\right)$. The SIMPER analysis showed that the most important taxa in to determinate differences among zones were Parakiefferiella, Ablabesmyia, Tanytarsini types A and B, Cricotopus/Orthocladius and Macropelopia (Table 1).

\section{Zone I $(17-12 \mathrm{~cm})$ pre-impact}

Ablabesmyia (Johannsen 1905) is relatively abundant in this zone, decreasing at $16 \mathrm{~cm}$ and $13 \mathrm{~cm}$. Macropelopia (Thienemann 1916) is at its highest abundance $(11 \%)$. Other taxa with high abundance in this zone are Parakiefferiella $(\sim 20 \%)$ (Thienemann 1936), Tanytarsini type A (35\%), and unidentified remains of Orthocladiinae (12\%). Pseudochironomus (Malloch 1915) only occurs in this zone but with very low abundances $(7 \%)$. The number of head capsules found in this zone is relatively high compared to the other zones, reaching ca. 15 heads per $\mathrm{ml}$ of wet sediment in some levels.

\section{Zone II (12-6 cm) during the impact}

In this zone, the Ablabesmyia abundance decreases, reaching its lowest value at $8 \mathrm{~cm}(6.8$ $\%$ ). Above $7 \mathrm{~cm}$, it starts to increase gradually. Macropelopia is at its lowest abundance in this zone (3.0\% average). Tanytarsini Type A decreases at the beginning of the zone, showing a transitory increase at $8 \mathrm{~cm} \mathrm{(17 \% ).} \mathrm{Tanytarsini}$ Type B is absent in the first part of this zone, appearing at $11 \mathrm{~cm}$, and increasing at the end of the zone $(14.6 \%)$. Another taxon that decreases gradually in abundance in this period is Cricotopus/Orthocladius (Wulp 1874). However, the greatest change in this zone is the increase of Parakiefferiella starting at $11 \mathrm{~cm}$, reaching abundances considerably higher than those found in the pre-impact zone $(25 \%)$. The highest abundances of head capsules were found before the tephra deposition; a noticeable drop is evident immediately after the event $(13-10 \mathrm{~cm})$, followed by an increase and subsequent decrease at 8 and $6 \mathrm{~cm}$, respectively.

\section{Zone III $(6-1 \mathrm{~cm})$ post-impact}

After the tephra deposition, some taxa start to increase rapidly. Ablabesmyia rises after $5 \mathrm{~cm}$, reaching its maximum at $3 \mathrm{~cm}(36.8 \%)$. Following the impact, both Macropelopia and Parachironomus (Lenz 1921), as well as other unidentified Tanytarsini and Tanypodinae also increase (11.1 and $26 \%)$. However, one of the most noticeable changes after the volcanic event is the decrease of Parakiefferiella, which had its highest abundance within the tephra layer. The total number of head capsules shows an increase at $4-5 \mathrm{~cm}$ and a decrease towards the uppermost surface sediments.

On the other hand, the diversity estimated by the Shannon index just shows slight changes along the profile. The main drops in chironomid diversity are in the centimetres 15 , 12,6 , and 3 , with the decrease at $12 \mathrm{~cm}$ corresponding to the deposition of the volcanic sediment. The equitability shows no noticeable changes as well, but a slight decrease is detected in the tephra layer $(7,8,9 \mathrm{~cm})$, which can be explained by a higher abundances of a few taxa like Parakiefferiella in that layer. 


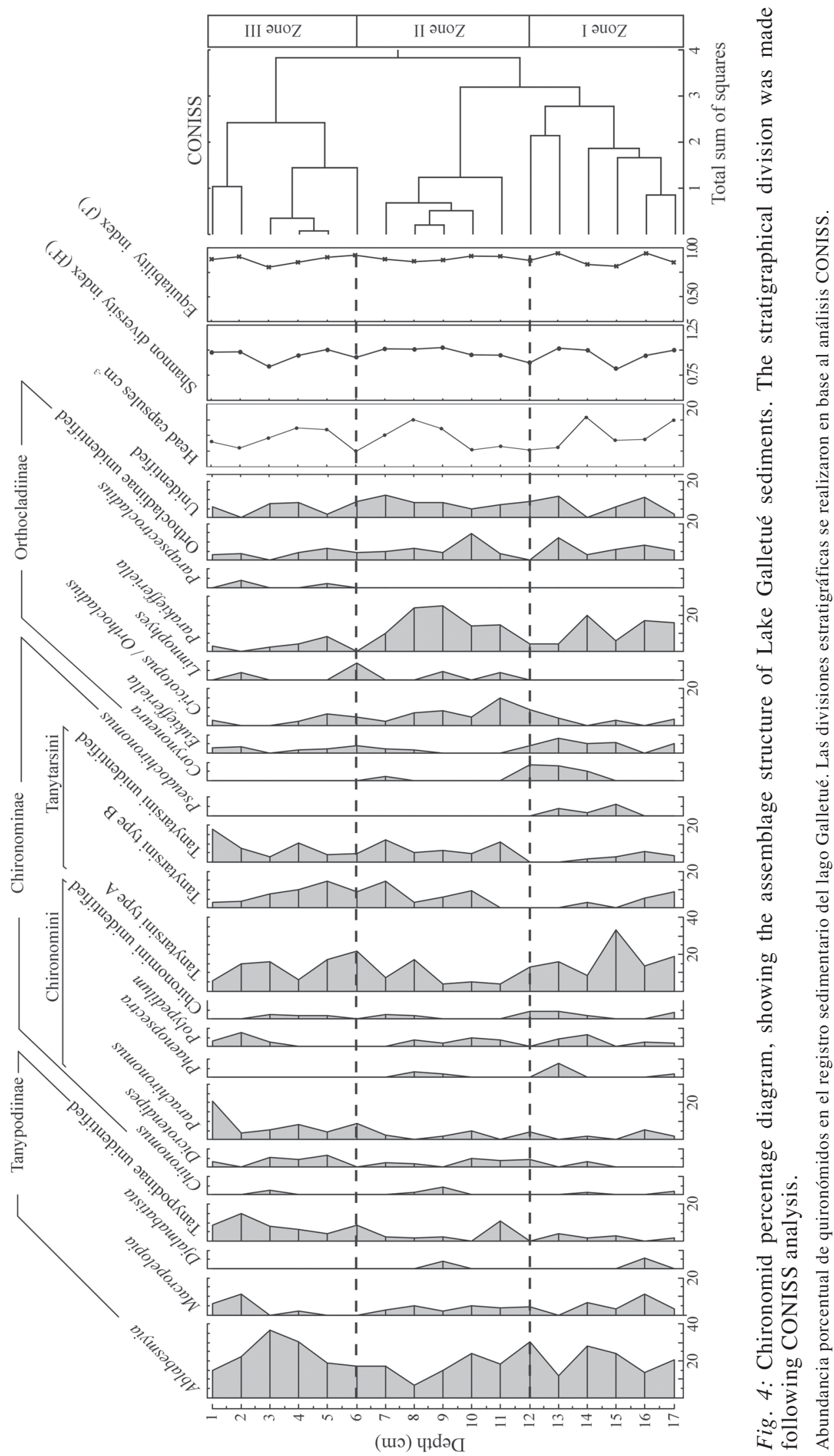


TABLE 1

Taxa contributions to differences (dissimilarity) among zones based on SIMPER analyses of abundances. Overall average dissimilarity values among the zones compared are indicated with asterisks

Contribuciones de los taxa a la diferencia (disimilaridad) entre zonas, de acuerdo al análisis SIMPER de las abundancias. Los valores promedio de disimilaridad global entre las zonas, se indican con asteriscos

\begin{tabular}{|c|c|c|c|c|c|c|}
\hline \multirow[t]{2}{*}{ Taxa } & \multicolumn{3}{|c|}{ Average abundance } & \multicolumn{3}{|c|}{ Average dissimilarity and contribution (\%) } \\
\hline & Zone I & Zone II & Zone III & I versus II $38.0^{*}$ & I versus III $39.4^{*}$ & II versus III $37.1^{*}$ \\
\hline Parakiefferiella & 6.0 & 6.3 & 1.3 & $2.9(7.5)$ & $3.8(9.5)$ & $4.0(10.7)$ \\
\hline Ablabesmyia & 9.0 & 5.8 & 8.8 & $2.0(5.3)$ & $2.3(6.0)$ & $1.9(5.1)$ \\
\hline Tanytarsini type A & 7.2 & 3.3 & 4.7 & $3.1(8.1)$ & $1.8(4.7)$ & $2.2(6.0)$ \\
\hline Tanytarsini type B & 1.8 & 2.2 & 3.2 & $2.6(6.8)$ & $2.7(7.0)$ & $2.7(7.3)$ \\
\hline Cricotopus/Ortho & 0.8 & 2.8 & 1.0 & $2.5(6.6)$ & $1.6(4.1)$ & $2.5(6.8)$ \\
\hline Macropelopia & 2.2 & 1.3 & 1.0 & $1.8(4.7)$ & $2.5(6.3)$ & $2.1(5.6)$ \\
\hline
\end{tabular}

\section{Ordination analysis}

In order to distinguish the relationship between chironomid assemblages and environmental variables associated with the tephra layer, ordination analyses were performed. A preliminary Detrended Correspondence Analysis (DCA) pointed out that the gradient lengths are short (i.e. $<2$ standard deviation units), indicating the usage of a linear model (ter Braak \& Prentice 1988). However, either a Principal Components Analysis (PCA) and a Redundancy Analysis (RDA) (as a direct gradient analysis) were performed using all the taxa and the two environmental variables that reflect the presence of the tephra layer: organic matter (OM) and grain size (Phi). The first axis of the PCA analysis explained $29.5 \%$ of the total variance of species data and, together, the first two axes explained $51.2 \%$ of the total variance (Table 2). The RDA explained a lower percentage of the data than did the PCA; the first two axes of the RDA accounted for only $22.7 \%$ of the total variance in the species data. The speciesenvironment correlations for the RDA were 0.73 (axis 1) and 0.81 (axis 2) (Table 2). The statistical significance of the relationship between the taxa and the environmental variables was evaluated through a Monte Carlo permutation test based on the RDA results. This analysis uses an $F$-ratio as a test statistic, which implies an $F$-value calculated from the data, denominated $F_{0^{-}}$by CANOCO, that is compared with a reference distribution. In contrast to other standard statistical tests where the reference distribution corresponds to the F-distribution, in the Monte Carlo test, this reference distribution is actually determined from the data through the permutations (ter Braak \& Smilauer 2002). In this case, 500 permutations were done for the Monte Carlo test, which showed that the first canonical axis is not significant at the $1 \%$ level $(\mathrm{P}=0.056$, Table 2$)$ but, at the same time, indicated that all canonical axes are statistically significant at the $1 \%$ level $(\mathrm{P}<0.01$, Table 2$)$, suggesting a relationship between species and the given environmental variables.

Fig. 5 depicts a biplot diagram of the ordination; the thick lines represent the environmental variables and thin lines the species. It is possible to see that Tanytarsina type B, Eukiefferiella (Thienemann 1926), Pseudochironomus, Ablabesmyia, Parachironomus, Dicrotendipes, Tanytarsina type A, and Parakiefferiella are highly important in structuring the assemblage. The taxa Ablabesmyia, Parapsectrocladius (Cranston 2000), and Limnophyes seem to be more influenced by high grain size (Phi) and organic matter values, whereas Cricotopus/Orthocladius, Djalmabatista, Chironomus (Meigen 1803), and especially Parakiefferiella appear to be sensitive to low Phi and organic matter values. It is important to clarify that Phi is a logarithmic scale of particle size in millimetres, which means high Phi values imply small particles. According to the ordination biplot, Parakiefferiella seems to prefer coarse grain over fine sediments. 
TABLE 2

CANOCO output of the ordination analysis, including (A) PCA, (B) RDA, and $(\mathrm{C})$ the Monte Carlo permutation test

Resultados de los análisis de ordenación realizados en CANOCO, incluyendo (A) ACP, (B) AR y (C) la prueba de Monte Carlo

\begin{tabular}{lcccc}
\hline (A) Summary of PCA analysis & & & & \\
\hline Axes & 1 & 2 & 3 & 0.156 \\
\hline Eigenvalues & 0.295 & 0.217 & 0.085 \\
Species-environment correlations & 0.654 & 0.183 & 0.480 & 0.767 \\
Cumulative percentage variance of species data & 29.5 & 51.2 & 66.7 & 75.3 \\
Cumulative percentage variance of species-environment relation & 55.6 & 58.7 & 74.5 & 1.00 \\
Sum of all eigenvalues & & & 0.22 \\
Sum of all canonical eigenvalues & & & & \\
\end{tabular}

(B) Summary of RDA analysis

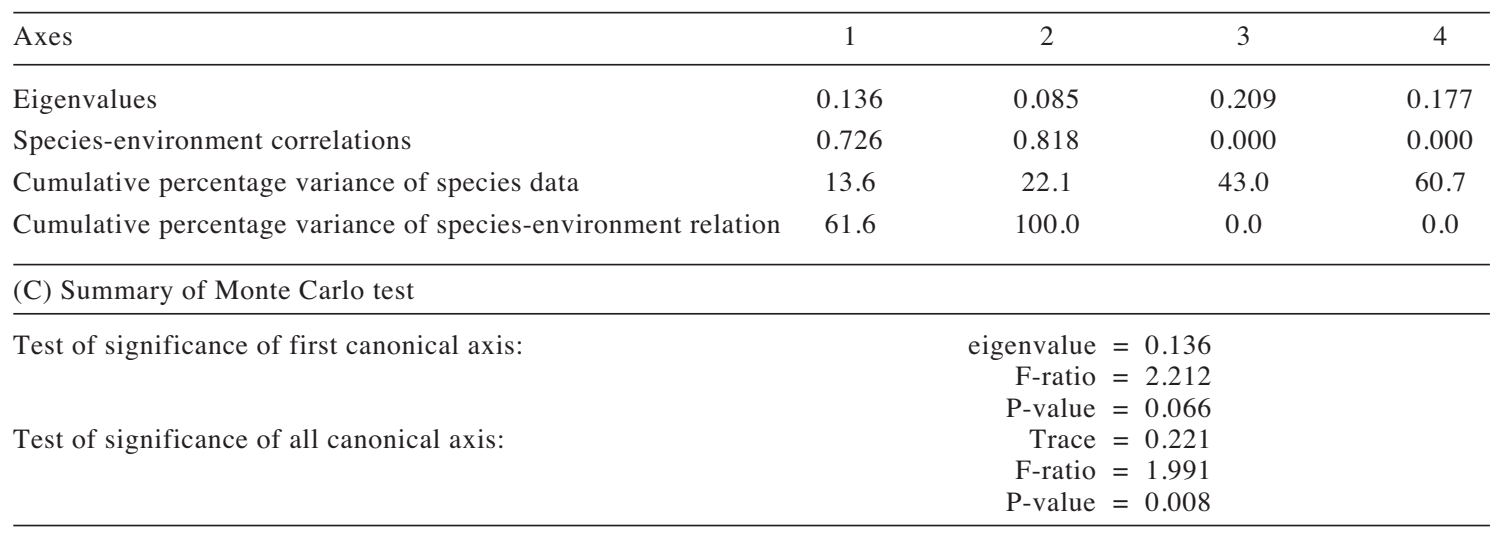

\section{DISCUSSION}

\section{Physical parameters}

The tephra layer deposited between 7 and 12 $\mathrm{cm}$ in the sediment of Lake Galletué produced a marked change in the lake's sedimentological structure. In terms of sedimentological properties, the tephra layer has a low organic content, coarse grain size, and lower ${ }^{210} \mathrm{~Pb}$ content in comparison with the rest of the core. Considering its mean size (equivalent to sand), it was probably deposited in a short period of time (Telford et al. 2004).

According to the dating $\left({ }^{210} \mathrm{~Pb},{ }^{137} \mathrm{Cs}\right)$, the sediment core covers the last $\sim 70$ years and the tephra deposition represents ca. 1957 AD. Some historical records of Andean volcanic activity (González-Ferran 1994) indicate that, in November 1956, an eruption of Llaima volcano, one of the biggest and most active in Chile (Moreno \& Fuentealba 1994), produced lava fluxes, ash expulsion, and lahars (González-Ferran 1994). Moreno and Gardeweg (1989) described the eruption of Lonquimay volcano (December 1989), another recent volcanic event near Lake Galletué. This eruption expelled ash, lava, and other pyroclastic materials, causing serious damage to crops and cattle in the region (Besoaín et al. 1992). However, this eruption does not coincide with the tephra deposition established by ${ }^{210} \mathrm{~Pb}$ dating. Therefore, the tephra layer deposited in Lake Galletué between 7 and 12 $\mathrm{cm}$ was probably generated by the Llaima volcano eruption of 1957.

The ${ }^{210} \mathrm{~Pb}$ profile shows a general decreasing trend from the upper part of the core to lower levels. However, it is possible to observe lower activity in centimetres 2,3 , and 4 as compared to 1 and 5. Other studies have also reported a similar trend of ${ }^{210} \mathrm{~Pb}$ profiles in Chile, where activity does not always decrease constantly with sediment depth (Urrutia et al. 
2000, Cisternas \& Araneda 2001, Arnaud et al. 2006). Cisternas \& Araneda (2001) attributed this reversal in activity to an increased sedimentation rate which, in turn, dilutes the ${ }^{210} \mathrm{~Pb}$ activity. Other causes of such an alteration include the mixing of sediments due to a seismic event or bioperturbation. In this short core from Lake Galletué, these two causes are discarded because the $\mathrm{x}$-rays revealed a horizontal arrangement of the sediment layers and the visual inspection did not identify biological mixing. Thus, the reversal in the activity could be attributed to differences in the sedimentation rate of Lake Galletué.

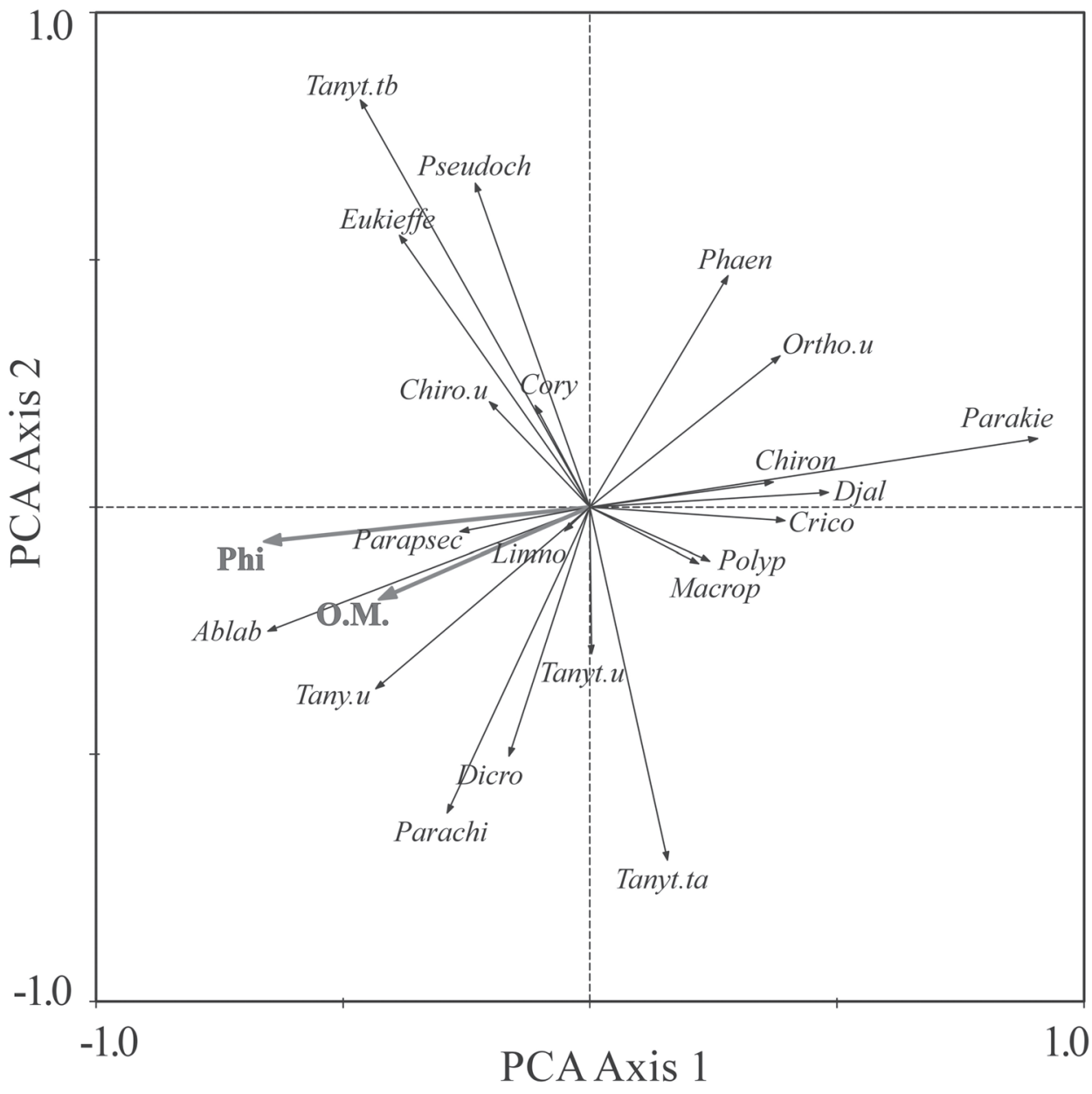

Fig. 5: Ordination biplot of Chironomid taxon with thin arrows representing taxon and thick arrows for environmental variables (Phi and OM). Taxa key as follows: Ablab = Ablabesmyia , Eukieffe $=$ Eukiefferiella, , Chiro.u = Chironomini unidentified, Pseudoch $=$ Pseudochironomus, Cory $=$ Corynoneura, Dicro = Dicrotendipes, Macrop = Macropelopia, Polyp = Polypedilum, Crico $=$ Cricotopus, Phaen $=$ Phaenopsectra, Parakie $=$ Parakiefferiella , Chiron $=$ Chironomus, Ortho $\cdot \mathrm{u}=$ Orthocladiinae unidentified, Djal $=$ Djalmabatista, Limno $=$ Limnophyes, Tanyt.ta $=$ Tanytarsini type A, Tanyt.tb = Tanytarsini type B, Parachi = Parachironomus, Tany $. \mathrm{u}=$ Tanypodinae unidentified, Parapsec $=$ Parapsectrocladius .

Biplot del análisis de ordenación de los taxa de quironómidos representadas por flechas finas y las variables ambientales; tamaño medio (Phi) y material orgánica $(\mathrm{OM})$, representadas por flechas gruesas. Abreviaciones como sigue: Ablab = Ablabesmyia, Eukieffe $=$ Eukiefferiella , Chiro.u $=$ Chironomini unidentified, Pseudoch $=$ Pseudochironomus, Cory $=$ Corynoneura , Dicro $=$ Dicrotendipes, Macrop $=$ Macropelopia, Polyp $=$ Polypedilum, Crico $=$ Cricotopus, Phaen $=$ Phaenopsec tra , Parakie $=$ Parakiefferiella, Chiron $=$ Chironomus, Ortho $. \mathrm{u}=$ Orthocladiinae unidentified, Djal $=$ Djalmabatista, Limno $=$ Limnophyes, Tanyt $. t a=$ Tanytarsini type A, Tanyt $. \mathrm{tb}=$ Tanytarsini type $\mathrm{B}$, Parachi $=$ Parachironomus, Tany $. \mathrm{u}=$ Tanypodinae unidentified, Parapsec = Parapsectrocladius. 


\section{Chironomids}

Some studies in the northern hemisphere have indicated that volcanic eruptions and associated processes have the potential to cause significant impacts on human and natural ecosystems (Eastwood et al. 2002). Among the impacts that a volcanic event could induce in aquatic ecosystems are increased nutrient input due to chemical weathering of tephra and changes in physical conditions such as diminishing light penetration (short term) that seals the sedimentwater interface or buries macrophytes in littoral zones. Other impacts might include changes in the $\mathrm{pH}$ and salinity of the lake water (Birks \& Lotter 1994, Heinrichs et al. 1999, Barker et al. 2000, Eastwood 2002).

These impacts, in turn, can produce changes in the organism assemblages living in the water column or sediment. Birks \& Lotter (1994) reported changes in diatom assemblages after a tephra deposition near Laacher See Volcano, Germany. They found that diversity and accumulation rates of some taxa of both terrestrial vegetation and diatoms at the sites nearest the volcano were affected after tephra deposition. Hickman \& Reasoner (1994), also working with diatoms but in British Columbia, found that tephra deposition affected diatom production, but could not find an effect on diatom diversity. Telford et al. (2004) described lacustrine responses to tephra falls, mainly represented in diatoms assemblages.

Regarding the effects caused by tephra on chironomids, Heinrichs et al. (1999) reported changes in assemblages at Kilpoola Lake (British Columbia) after the deposition of the Mazama ash layer. Above the tephra layer, these authors found increased Cricotopus/ Orthocladius abundance which, together with other characteristics of the assemblage, indicated increased salinity as a direct result of volcanic deposition. Tsukada (1967) also reported a decrease in Tanytarsus genuinus abundance after two events of volcanic sediment deposition in Lake Nojiri, Japan.

Massaferro \& Corley (1998) used subfossil chironomid assemblages from Lake Mascardi ( $41^{\circ} 20^{\prime} \mathrm{S}, 71^{\circ} 34^{\prime} \mathrm{W}$ ) covering ca. $15 \mathrm{kyr} \mathrm{BP}$ to show that the most important factors affecting chironomid distribution in this lake are volcanism and climate cooling. They found sharp changes in chironomid diversity and equitability after the deposition of tephra layers that caused extreme conditions unsuitable for many species. Their results also indicate the complete absence of chironomid fauna within the tephra layers and a rapid recovery of diversity and equitability to their predisturbance levels once the tephra deposition had terminated.

Massaferro et al. (2005) found evidence of tephra impacts on chironomid fauna in Lake Morenito $\left(41^{\circ} \mathrm{S}, 71^{\circ} \mathrm{W}\right)$. The abundance and diversity of chironomids decreased drastically along with organic content during episodes of volcanic sediment deposition. However, these authors pointed out that the most important fluctuation in chironomid assemblages was due to the anthropic disturbances of the watershed, reflected by the increased abundance of Chironomus, a typical inhabitant of mesotrophic and eutrophic environments. Human intervention in the lake by dam construction and a volcanic event in 1960 provoked increased diversity and the reappearance of Ablabesmyia, Paracladopelma, Phaenopsectra, and Dicrotendipes taxa. Massaferro et al. (2005) suggest that the increase in Chironomus towards the upper part of the core and the decline of Tanytarsus $g r$., together with increased OM, could reflect more productive conditions within the lake. Nevertheless, they suggest that, due to the synchronicity of both the natural (1960 volcanic event) and anthropic (dam construction) impacts, it is difficult to track a direct cause and effect relationship for the changes in the chironomid assemblages.

Overall, our results from Lake Galletué indicate a decrease in the concentration of head capsules just after the tephra deposition, although this concentration increased later in the tephra layer. Within the tephra, Parakiefferiella increased noticeably, whereas Ablabesmyia fell in the same strata. The difference in abundance of these taxa indicates that the tephra deposition could have provided an advantage to Parakiefferiella in comparison with other taxon like Ablabesmyia, which was affected negatively. In the ordination biplot, Parakiefferiella is negatively correlated with high values of Phi and OM, suggesting that this taxon is more abundant in coarse grains and with low organic matter. Conversely, Ablabesmyia is positively correlated with both 
variables, probably being more abundant with small grain sizes. Unfortunately, there is little ecological knowledge about chironomids in Chile that can help to interpret such changes, but some information generated elsewhere indicates that Parakiefferiella is a taxon typical of cold, well-oxygenated waters (Massaferro \& Corley 1998, Porinchu \& Cwynar 2002). Thus, the coarse $(\sim 300 \mu \mathrm{m}$ up to $1 \mathrm{~cm})$, highly porous tephra of Galletué could have maintained a higher oxygen level, more favourable to Parakieferiella.

There are others features of chironomid assemblages within the tephra layer. One is the slight increase of Cricotopus/Orthocladius, which has low abundances both before and after the tephra layer. This behaviour coincides with the increment of the same taxon determined by Heinrichs et al. (1999) after a tephra deposition in British Columbia, associated with an increase in salinity due to volcanic sediment deposition. It is also possible to see the disappearance of Pseudochironomus and Corynoneura, and the appearance of Limnophyes, Chironomus, Phaenopsectra and Djalmabatista. On the other hand, after the tephra deposition, it is possible to see a slight recovery in some chironomid taxa, which maintain low abundances during the tephra, like Ablabesmyia, Eukiefferiella, and Parachironomus. This suggests that the lake could have a resilience capacity currently tending to re-establish the conditions prevailing before the tephra deposition.

Although our results do not show a drastic change in chironomid diversity reflected in the Shannon index, the changes in the assemblages mentioned above no doubt indicated that tephra had an impact on the Lake Galletué chironomids. Previous investigations report changes in chironomid diversity during tephra depositions (Massaferro \& Corley 1998, Massaferro et al. 2005), and we suggest such differences could be explained by the characteristics of the tephra.

According to Lowe \& Hunt (2001), the term "tephra" is a general term used for a broad range of sediments released from volcanic eruptions. Therefore, tephra characteristics vary greatly between different geographical zones or even between eruptions of the same volcano. The tephra of Lake Galletué is composed mainly of coarse particles $(\sim 300 \mu \mathrm{m}$ up to 1 $\mathrm{cm}$ ) with high porosity that seem to be favourable to Parakiefferiella. Although Massaferro \& Corley (1998) and Massaferro et al. (2005) do not present a sedimentological characterization of the tephra layers identified in their profiles, it is possible that the tephra in Lakes Mascardi and Morenito have completely different characteristics than the tephra found in Lake Galletué. For example, volcanic sediment that is finer (less porous) or more soluble (changes in $\mathrm{pH}$ or salinity) could have had a different effect on the chironomid assemblages in Lake Galletué, which may have been reflected as changes in diversity.

Massaferro \& Corley (1998) found that head capsules were completely absent in the tephra layer. In our results, we report a drop in the abundance of head capsules at the beginning of the tephra deposition but, shortly after, an increase all along the tephra layer.

According to Telford et al. (2004), the effects of tephra on aquatic biota are evident once the tephra is deposited because sedimentation of tephra particles (assuming an equivalent size to sand) is fast $\left(\sim 40 \mathrm{~m} \mathrm{~h}^{-1}\right)$. These authors indicate that the presence of diatom remains within the tephra could be a result of sediment mixing processes. This statement also should be valid for our results, because we found chironomid remains within the tephra. The mixing of tephra particles with the host sediment is also evident at the beginning of tephra deposition (11 cm, Fig. 3). However, the tephra recorded in Lake Galletué is very coarse, with particles as large as $1 \mathrm{~cm}$ in diameter; thus, the high porosity could have allowed the percolation of fine sediments (S. Bertrand, unpublished data, 2004) and also the input of chironomids and diatoms (Cruces et al. 2006) towards the tephra layer.

\section{CONCLUSIONS}

The sedimentary record of Lake Galletué provides evidence of a $5-\mathrm{cm}$ thick layer of volcanic sediment (tephra) deposited during a recent eruption near the watershed. The deposition of this tephra produced an interruption in the normal deposition of sediment, differing completely in mineralogical composition, organic content, and ${ }^{210} \mathrm{~Pb}$ activity from the host sediment. The geochronology 
established by ${ }^{210} \mathrm{~Pb}$ and ${ }^{137} \mathrm{Cs}$, along with the volcanic history of the area, indicate that this tephra deposition probably corresponds to the 1956-1957 eruption of the Llaima volcano.

This tephra deposition also generated changes in the aquatic biota assemblages, as reflected by diatoms. Our results also identified an impact on chironomid assemblages due to this deposition. The most noticeable change in the chironomid assemblage is the marked increase of Parakiefferiella within the tephra layer, and the decrease of Ablabesmyia in the same layer. After the tephra layer, a recovery was observed in the abundance of some taxa that were sensitive to the tephra deposition, suggesting that the lake has enough of a resilience capacity to restore the conditions prevailing before the impact.

On the other hand and contrary to our expectations, the tephra deposition did not produce a drastic change in the chironomid diversity index, as reported in other studies. We suggest that the properties of the tephra deposition (mineralogy, grain size, porosity, solubility) explain these different results.

\section{ACKNOWLEDGEMENTS}

This research was funded by projects Dirección de Investigación Universidad de Concepción (DIUC) numbers 204.310.039-1.0, 203.310.351.0, and by FONDECYT 1050647 and partially 1070508. Special thanks to A. Paggi for a warm reception in her lab during training in chironomid taxonomy; to I. Walker and S. Brooks for their help with taxonomical doubts; to C. Vivero for her valuable help with samples; and to E. Habit and R. Figueroa for help with statistical analysis. A.A. is grateful for a scholarship from Escuela de Graduados, Universidad de Concepción, and thanks Wallonia Community (Belgium) for funding a research stay and E. Chapron for his assistance in the fieldwork. Finally, this work would not have been possible without the loving support of my wife, Karina.

\section{LITERATRA CITED}

ADRIAENSSENS V, F SIMONS, LT NGUYEN, B GODDEERIS, PL GOETHALS \& ND PAUW (2004) Potential of bio-indication of chironomid communities for assessment of running water quality in Flanders (Belgium). Belgian Journal of Zoology 134: 31-40.

ANDERSEN T (1996) A new species of Monodiamesa Kieffer, 1922 from southern Chile (Diptera: Chironomidae: Prodiamesinae). Revista Chilena de Entomología 23: 43-49.

APPLEBY PG \& F OLDFIELD (1978) The calculation of lead-210 dates assuming a constant rate of supply of unsupported ${ }^{210} \mathrm{~Pb}$ to the sediment. Catena $5: 1-8$.

ARENAS J (1995) Composición y distribución del macrozoobentos del curso principal del río Biobío, Chile. Medio Ambiente (Chile) 12: 39-50.

ARNAUD F, O MAGAND, E CHAPRON, S BERTRAND, $X$ BOES, F CHARLET \& MA MELIERES (2006) Radionuclide dating $(210 \mathrm{~Pb}, 137 \mathrm{Cs}, 241 \mathrm{Am})$ of recent lake sediments in a highly active geodynamic setting (lakes Puyehue and Icalma-Chilean Lake District). Science of the Total Environment 366: 837-850.

AXELSSON V (1993) The use of x-ray radiographic methods in studying sedimentary properties and rates of sediments accumulation. Hydrobiologia 103: $65-69$.

BARKER P, R TELFORD, Q MERDACI, D WILLIAMSON, M TAIEB, A VINCENS \& E GILBERT (2000) The sensitivity of a Tanzanian crater lake to catastrophic tephra input and four millennia of climate change. Holocene 10: 303-310.

BESOAÍN E, G SEPÚLVEDA \& A SADZAWKA (1992) La erupción del volcán Lonquimay y sus efectos en la agricultura. Agricultura Técnica (Chile) 52: 354-358.

BIRKS HJB \& AF LOTTER (1994) The impact of the Laacher See volcano (11000 yr B.P.) on terrestrial vegetation and diatoms. Journal of Paleolimnology 11: 313-322.

BOYLE JF (2002) Mineralogical and geochemical indicator techniques. In: Last W \& JP Smol (ed) Tracking environmental change using lake sediments: 83-141. Springer-Verlag, New York, New York, USA.

BROOKS SJ (2000) Lateglacial fossil midge (Insecta: Diptera: Chironomidae) stratigraphies from the Swiss Alps. Palaeogeography, Palaeoclimatology, Palaeoecology 159: 261-279.

BROOKS SJ \& HJB BIRKS (2000) Chironomid-inferred late-glacial and early-Holocene mean july air temperatures for Krakenes lake, western Norway. Journal of Paleolimnology 23: 77-89.

BROOKS SJ, H BENNION \& HJB BIRKS (2001) Tracing lake trophic history with a chironomid-total phosphorus inference model. Freshwater Biology 46: 513-533.

BROOKS SJ \& HJB BIRKS (2004) The dynamics of Chironomidae (Insecta: Diptera) assemblages in response to environmental change during the past 700 years on Svalbard. Journal of Paleolimnology 31: 483-498.

BRUNDIN L (1983) Chilenomya paradoxica gen. n., sp. and Chilenomyiinae, a new subfamily among the Chironomidae (Diptera). Entomologica Scandinavica 14: 33-45.

CISTERNAS M \& A ARANEDA (2001) Variaciones isotópicas $(210 \mathrm{~Pb}, 137 \mathrm{Cs})$ antropogénicas en el registro estratigráfico de una lago de la cordillera de Nahuelbuta, Chile. Revista Geológica de Chile 28: $105-115$.

CLARKE KR, WARWICK RM, SOMERFIELD PJ \& RN GORLEY (2005) Change in marine communities: an approach to statistical analysis and 
interpretation. Third edition. PRIMER-E Ltd., Plymouth, United Kingdom. 144 pp.

CLARKE KR AND GORLEY RN (2005) PRIMER v.6: User Manual / Tutorial. PRIMER-E Ltd., Plymouth, United Kingdom. $91 \mathrm{pp}$

CRUCES F, R URRUTIA, O PARRA, A ARANEDA, HC TREUTLER, S BERTRAND, N FAGEL, L TORRES, R BARRA \& R CHIRINOS (2006) Changes in diatom assemblages in an Andean lake ( $38^{\circ} 41^{\prime} \mathrm{S}, 71^{\circ} 17$ 'W, IX Region-Chile) in response to a recent volcanic event. Archiv für Hydrobiologie 165: 23-35.

EASTWOOD WJ, J TIBBY, N ROBERTS, HJB BIRKS \& HF LAMB (2002) The environmental impact of the Minoan eruption of Santorini (Thera): statistical analysis of palaeocological data from Gölhisar, southwest Turkey. Holocene 12: 431-444.

EPLER JH (2001) Identification Manual for the larval Chironomidae (Diptera) of North and South Carolina. A guide to the taxonomy of the midges of the southeastern United States, including Florida. North Carolina Department of Environment and Natural Resources, Crawfordville, Florida, USA. $526 \mathrm{pp}$.

GONZÁLEZ-FERRAN O (1994) Volcanes de Chile. Instituto Geográfico Militar, Santiago, Chile. 635 pp.

HEINRICHS ML, SE WILSON, IR WALKER, JP SMOL, RW MATHEWES \& KJ HALL (1997) Midge- and diatom-based palaeosalinity reconstructions for Mahoney lake, Okanagan Valley, British Columbia, Canada. International Journal of Salt Lake Research 6: 249-267.

HEINRICHS ML, IR WALKER, RW MATHEWES \& RJ HEBDA (1999) Holocene chironomid-inferred salinity and paleovegetation reconstruction from Kilpoola lake, British Columbia. Geographie physique et Quaternaire 53: 211-221.

HICKMAN M \& MA REASONER (1994) Diatom responses to late Quaternary vegetation and climate change, and to deposition of two tephras in an alpine and sub-alpine lake in Yoho National Park, Bristish Columbia. Journal of Paleolimnology 11: 173-188.

HOFMANN W (1971) Zur taxonomie und palokologie subfossiler Chironomiden (Dipt.) in seesedimenten. Ergebnisse der Limnologie 6: 1-50.

LAROCQUE I, RI HALL \& E GRAHN (2001) Chironomids as indicators of climate change: a 100lake training set from a subartic region of northern Sweden (Lapland). Journal of Paleolimnology 26: 307-322.

LITTLE JL \& JP SMOL (2001) A chironomid -based model for inferring late-summer hypolimnetic oxygen in southeastern Ontario lakes. Journal of Paleolimnology 26: 259-270.

LONGMORE ME, BM O'LEARY \& CW ROSE (1983) Cesium-137 profiles in the sediment of a partialmeromitic lake on Great Sandy Island, Queensland, Australia. Hydrobiologia 103: 21-27.

LOTTER AF \& HJB BIRKS (1993) The impact of the Laacher See Tephra on terrestrial and aquatic ecosystems in the Black Forest, southern Germany. Journal of Quaternary Science 8: 263-276.

LOWE DJ \& JB HUNT (2001) A summary of terminology used in tephra-related studies. In: Juvigné E \& JP Raynal (ed) Tephra: chronology, archaeology: 1722. CDERAD éditeur: Goudet, France.

MARDONES M, E UGARTE, M RONDANELLI, A RODRÍGUEZ \& C BARRIENTOS (1993)
Planificación ecológica en el sector Icalma-Liucura (IX Región): proposición de un método. In: Faranda F \& O Parra (ed) Monografías Científicas EULA: 47-63. Ediciones Universidad de Concepción, Concepción, Chile.

MASSAFERRO J \& J CORLEY (1998) Environmental disturbance and chironomid paleodiversity: $15 \mathrm{kyr}$ BP of history at Lake Mascardi, Patagonia, Argentina. Aquatic Conservation: Marine and Freshwater Ecosystems 8: 315-323.

MASSAFERRO J \& SJ BROOKS (2002) Response of chironomids to late Quaternary environmental change in the Taitao peninsula, southern Chile. Journal of Quaternary Science 17: 101-111.

MASSAFERRO J, SJ BROOKS \& KA JACKSON (2002) Estudio preliminar de la distribución y composición de las comunidades de quironómidos (Diptera: Chironomidae) en el parque nacional Laguna San Rafael ( $\left.46^{\circ} \mathrm{S}\right)$, Chile. Boletín del Museo Nacional de Historia Natural (Chile) 51: 123-134.

MASSAFERRO J, S RIBEIRO-GUEVARA, A RIZZO \& M ARRIBÉRE (2005) Short-term environmental changes in Lake Morenito $\left(41^{\circ} \mathrm{S}, 71^{\circ} \mathrm{W}\right.$, Patagonia, Argentina) from the analysis of sub-fossil chironomids. Aquatic Conservation: Marine and Freshwater Ecosystems 15: 23-30.

MORENO H \& M GARDEWEG (1989) La erupción reciente en el complejo volcánico Lonquimay (Diciembre 1988-), Andes del Sur. Revista Geológica de Chile 16: 93-117.

MORENO H \& G FUENTEALBA (1994) The May 17-19 1994 Llaima volcano eruption, southern Andes ( $\left.38^{\circ} 42^{\prime} \mathrm{S}-71^{\circ} 44^{\prime} \mathrm{W}\right)$. Revista Geológica de Chile 21: $167-171$

OLANDER H, A KORHOLA \& T BLOM (1997) Surface sediment Chironomidae (Insecta: Diptera) distributions along an ecotonal transect in subartic Fennoscandia: developing a tool for paleotemperatures reconstructions. Journal of Paleolimnology 18: 45-59.

PAGGI A (2001) Diptera: chironomidae. In: Fernández HR \& E Domínguez (ed) Guía para la determinación de los artrópodos bentónicos sudamericanos: 167-194. Editorial Universitaria de Tucumán, Tucumán, Argentina.

PARRA O, H CAMPOS, W STEFFEN, G AGUERO, S BASUALTO, D AVILÉS \& M VIGHI (1993) Estudios limnológicos de los lagos Icalma y Galletué: lagos de origen del río Biobío (Chile central). In: Faranda F \& O Parra (ed) Evaluación de la calidad del agua y ecología del sistema limnético y fluvial del río Biobío: 161-188. Ediciones Universidad de Concepción, Concepción, Chile.

PORINCHU DF \& LC CWYNAR (2002) Late-Quaternary history of midge communities and climate from a tundra site near the lower Lena river, northeast Siberia. Journal of Paleolimnology 27: 59-69.

QUINLAN R \& JP SMOL (2001) Chironomid-based inference models for estimating end-of-summer hypolimnetic oxygen from south-central Ontario shield lakes. Freshwater Biology 46: 1529-1551.

RIERADEVALL M \& SJ BROOKS (2001) An identification guide to subfossil Tanypodinae larvae (Insecta: Diptera: Chironomidae) based on cephalic setation. Journal of Paleolimnology 25: 81-99.

TELFORD RJ, $P$ BARKER, S METCALFE \& A NEWTON (2004) Lacustrine responses to tephra deposition: examples from Mexico. Quaternary Science Reviews 23: 2337-2353. 
TER BRAAK CJF \& P SMILAUER (2002) CANOCO reference manual and CanoDraw for windows user's guide: software for canonical community ordination (version 4.5). Microcomputer Power, Ithaca, New York, USA. 500 pp.

TER BRAAK CJF \& IC PRENTICE (1988) A theory of gradient analysis. Advances in Ecological Research 18: 271-317.

TSUKADA M (1967) Successions of Cladocera and benthic animals in Lake Nojiri. Japanese Journal of Limnology 10: 107-123.

URRUTIA R, K SABBE, F CRUCES, K POZO, J BECERRA, A ARANEDA, W VYVERMAN \& O PARRA (2000) Paleolimnological studies of Laguna Chica de San Pedro (VIII region): diatoms, hydrocarbons and fatty acid records. Revista Chilena de Historia Natural 73: 717-728.

Associate Editor: Claudio Latorre

Received May 19, 2006; accepted November 20, 2006
WALKER IR (1987) Chironomidae (Diptera) in paleoecology. Quaternary Science Reviews 6: 29 40 .

WALKER IR, JP SMOL, DR ENGSTROM \& HJB BIRKS (1991) An assessment of Chironomidae as quantitative indicators of past climatic change. Canadian Journal of Fisheries and Aquatic Sciences 48: 975-987.

WALKER IR, SE WILSON \& JP SMOL (1995) Chironomidae (Diptera): quantitative paleosalinity indicators for lakes of western Canada. Canadian Journal of Fisheries and Aquatic Sciences 52: 950960.

WIEDERHOLM T (1983) Chironomidae of the holartic region. Keys and diagnoses. Part I - Larvae. Entomologica Scandinavica Supplement 19: 1-457. 